\title{
Electrochemical Degradation of Lincomycin in Prepared and Environmental Aqueous Matrices
}

\author{
Te-San Chen, Jhao-Jia Jheng, Kuo-Lin Huang ${ }^{*}$, Hei Man Cheng \\ Department of Environmental Science and Engineering, National Pingtung University of Science and \\ Technology, Pingtung 91201, Taiwan (ROC) \\ *E-mail: huangk1@mail.npust.edu.tw
}

doi: $10.20964 / 2017.12 .700$

Received: 23 September 2017 / Accepted: 27 October 2017 / Published: 12 November 2017

This study focuses on the performance of lincomycin (LC) electro-degradation in terms of LC degradation and total organic carbon (TOC) removal efficiencies. The LC degradation and TOC removal under several parameters, such as electrolytic cell (undivided vs. divided), current density, anode material (BDD, $\mathrm{PbO}_{2}$, and $\mathrm{Pt}$ ), and real environmental water matrix (municipal wastewater treatment plant secondary effluent (MWTPSE), groundwater (GW), and river water (RW)) were investigated and discussed. The results show that the electrochemical degradation of LC followed pseudo-first-order kinetics and the LC degradation efficiency and TOC removal increased with the increase in current density. The performance of LC degradation and TOC removal on the tested electrodes was in the order $\mathrm{BDD}>\mathrm{PbO}_{2}>\mathrm{Pt}$. The faster $\mathrm{LC}$ degradation occurred in the undivided cell, but the TOC removal was better in the divided cell. At $0.5 \mathrm{~A} / \mathrm{cm}^{2}$ and $25^{\circ} \mathrm{C}$ in $1 \mathrm{M} \mathrm{Na}_{2} \mathrm{SO}_{4}$, the apparent rate constants of LC degradation were $5.23 \times 10^{-3}$ and $2.33 \times 10^{-3} \mathrm{~s}^{-1}$ in the undivided and divided cells, respectively. Using this electrochemical oxidation process could completely mineralize the LC and TOC in the three different environmental matrices with the order GW > RW > MWTPSE.

Keywords: lincomycin; pharmaceuticals and personal care products (PPCPs); electro-degradation; boron-doped diamond electrode

\section{FULL TEXT}

(C) 2017 The Authors. Published by ESG (www.electrochemsci.org). This article is an open access article distributed under the terms and conditions of the Creative Commons Attribution license (http://creativecommons.org/licenses/by/4.0/). 